\title{
Circulatory support with venoarterial ECMO in a patient with biventricular Takotsubo cardiomyopathy
}

\section{Soporte circulatorio con ECMO venoarterial en paciente con cardiomiopatía de Takotsubo biventricular}

\author{
Emmanuel A. Lazcano-Díaz ${ }^{*}$, Francisco J. González-Ruíz², Diego Sarre-Álvarez³, \\ Rolando J. Álvarez-Álvarez², Eduardo Bucio-Reta², Edgar García-Cruz², Gustavo Rojas-Velasco², \\ Ángel Ramos-Enríquez², Efrén Melano-Carranza², Luis E. Santos-Martínez², and \\ Francisco M. Baranda-Tovar \\ ${ }^{1}$ Department of Cardiovascular Intensive Therapy; ${ }^{2}$ Department of Postsurgical Therapy; ${ }^{3}$ Department of Cardiology; ${ }^{4}$ Sub-directorate. Instituto \\ Nacional de Cardiología Ignacio Chávez de México, Mexico City, Mexico
}

\begin{abstract}
Takotsubo cardiomyopathy is an entity characterized by acute and transient ventricular dysfunction, which is usually related to a triggering event (emotional or physical stress), and usually presents with regional systolic dysfunction of the left ventricle, however up to $30 \%$ may be biventricular. Depending on its severity in some cases, the disease can condition refractory cardiogenic shock to management with inotropics and vasopressors, so for these cases circulatory assistance devices should be considered. We present the case of a young patient who had pulmonary valve change with biological prosthesis, which 7 weeks after surgery went to the emergency department with pericardial effusion and tamponade physiology secondary to postpericardiotomy syndrome. For this reason pericardial window was practiced; however, during the procedure she presented biventricular Takotsubo cardiomyopathy which conditioned cardiogenic shock with severe mitral and tricuspid regurgitation, and refractivity to medical treatment as well as intra-aortic balloon pump, requiring circulatory support with venoarterial ECMO for 5 days.
\end{abstract}

Key words: Takotsubo cardiomyopathy. Ventricular dysfunction. Cardiogenic shock. Venoarterial ECMO.

\section{Resumen}

La cardiomiopatía de Takotsubo es una entidad caracterizada por disfunción ventricular aguda y transitoria, la cual está generalmente relacionada a un evento desencadenante (estrés emocional o físico) y que, por lo general, se presenta con disfunción sistólica regional del ventrículo izquierdo, aunque hasta en un 30\% puede ser biventricular. Según su severidad, en algunos casos puede condicionar choque cardiogénico refractario a manejo con inotrópicos y vasopresores, por lo que para estos casos deben considerarse los dispositivos de asistencia circulatoria. Presentamos el caso de una paciente joven a quien se realizó cambio valvular pulmonar con prótesis biológica, la cual siete semanas posteriores a la cirugía acudió al servicio de urgencias con derrame pericárdico y fisiología de tamponade secundario a síndrome pospericardiotomía. Por tal motivo se le practicó ventana pericárdica, sin embargo durante el transquirúrgico presentó cardiomiopatía de Takotsubo biventricular que le condi-

Correspondence:

*Emmanuel A. Lazcano-Díaz

E-mail: ea.lazcano.diaz@gmail.com
Date of reception: 05-02-2020

Date of acceptance: 10-05-2020

DOI: 10.24875/ACME.M21000178
Available online: 25-05-2021

Arch Cardiol Mex (Eng). 2021;91(1):90-94 www.archivoscardiologia.com 2604-7063 / @ 2020 Instituto Nacional de Cardiología Ignacio Chávez. Published by Permanyer. This is an open access article under the CC BY-NC-ND license (http://creativecommons.org/licenses/by-nc-nd/4.0/). 
cionó choque cardiogénico con insuficiencia mitral y tricúspidea severas y refractariedad a tratamiento médico, así como a balón intraaórtico de contrapulsación (BIAC), por lo cual requirió soporte circulatorio con ECMO venoarterial durante 5 días.

Palabras clave: Cardiomiopatía de Takotsubo. Disfunción ventricular. Choque cardiogénico. ECMO venoarterial.

\section{Introduction}

We present the case of a 37-year-old female patient with a history of double lung injury (stenosis predominance) who underwent pulmonary valve exchange for biological prosthesis without perioperative complications. She was discharged home asymptomatic, with preserved biventricular function. However, 6 weeks after the surgical procedure he presented with dyspnea on moderate to small exertion, ascending edema of pelvic limbs, and pleuritic-type pain, which is why she attended the emergency department, where she was admitted with a tendency to hypotension, pericardial friction rub, significant edema of extremities, electrocardiogram with sinus tachycardia, low-voltage QRS complexes, and electrical alternans. Chest X-ray and pulmonary ultrasound with significant bilateral pleural effusion. Relevant laboratory findings with: $\mathrm{N}$-terminal pro B-type natriuretic peptide (NT-proBNP) $2.305 \mathrm{pg} / \mathrm{mL}$, high-sensitivity troponin $2.3 \mathrm{ng} / \mathrm{mL}$, and C-reactive protein (CRP) $121 \mathrm{mg} / \mathrm{L}$. Focused echocardiogram reported global pericardial effusion of $49 \mathrm{~mm}$ with transmitral variability in $53 \%$, transtricuspid variability of $39 \%$, right atrial collapse, and preserved biventricular function without mobility disorders. In view of the hemodynamic repercussions, a pericardial window was performed, whereby $1000 \mathrm{cc}$ of serous fluid were drained; endopleural tubes were also placed, whereby $1200 \mathrm{cc}$ of serous fluid were drained. Both procedures had an exudate cytochemical report with inflammatory characteristics and negative culture. After the pericardial window, the patient was transferred to post-operative therapy, where she arrived hypotensive, with data consistent with systemic hypoperfusion. A new electrocardiogram showed lengthening of the QTc interval, as well as $T$ waves inversion on anterior aspects (Fig. 1); a new echocardiogram showed depressed biventricular function, left ventricle with akinesia in the middle and apical region with compensatory hyperkinesia of the basal third on all aspects; left ventricular ejection fraction (LVEF) was $15 \%$ by modified Simpson, strain-3\%, (Fig. 2), three-dimensional LVEF was 20\%; right ventricle with akinesia on basal and apical thirds, and basal hyperkinesia, as well as right ventricular outflow tract fractional shortening (RVOT-FS) of $15 \%$, suggestive of biventricular Takotsubo cardiomyopathy without obstruction of the left ventricular outflow tract (Fig. 3). In addition, severe mitral and tricuspid regurgitation associated with tethering was reported (Figs. 4 and 5). Troponins were measured again with elevation to up to $3200 \mathrm{ng} / \mathrm{mL}$ and NT-proBNP to $4000 \mathrm{pg} / \mathrm{mL}$. As for hemodynamic profile, on cardiogenic shock, and management with double inotropic (levosimendan and dobutamine) and double vasopressor (norepinephrine and vasopressin) was therefore started; however, she persisted with a heart rate of $1.4 \mathrm{~b} / \mathrm{min}$ and data consistent with systemic hypoperfusion; therefore, placing an intra-aortic balloon pump (IABP) was decided. Despite the employed therapy, the patient continued on refractory cardiogenic shock, with respiratory compromise requiring orotracheal intubation, and showing liver and kidney dysfunction. For this reason, $12 \mathrm{~h}$ after IABP therapy initiation, extracorporeal membrane oxygenation (ECMO) was added for femoral venous and femoral arterial cannulation, with the flow being titrated to up to $2.5 \mathrm{~L} / \mathrm{min}$. During circulatory support, evolution was adequate, with hemodynamic stabilization, and amines and inotropes could be withdrawn in the first $4 \mathrm{~h}$, with subsequent improvement in kidney and liver function, as well as a decrease in pulmonary congestion, with extubation being achieved within the first $48 \mathrm{~h}$. As for biventricular function, there was clear progressive improvement (until LVEF of $35 \%$, velocity time integral [VTI] of $14 \mathrm{~cm}$, lateral mitral "s" velocity of 8 $\mathrm{cm} / \mathrm{s}$, and RVOT-FS of $30 \%$ were achieved), with remission of contractility segmental alterations and decrease in valve disease severity (to a mild grade), without ECMO-related complications, and therapy was, therefore, successfully discontinued at 5 days.

Subsequently, she was transferred to the cardiology area, where she underwent cardiac magnetic resonance imaging, with no mobility disorders, preserved biventricular function, no valve insufficiency, and a normally-functioning lung bioprosthesis being reported.

\section{Literature review}

We present the case of a patient who developed postpericardiotomy syndrome 7 weeks after cardiac surgery, which according to the literature has a prevalence of up to $10-40 \%$ and can occur from a few days 


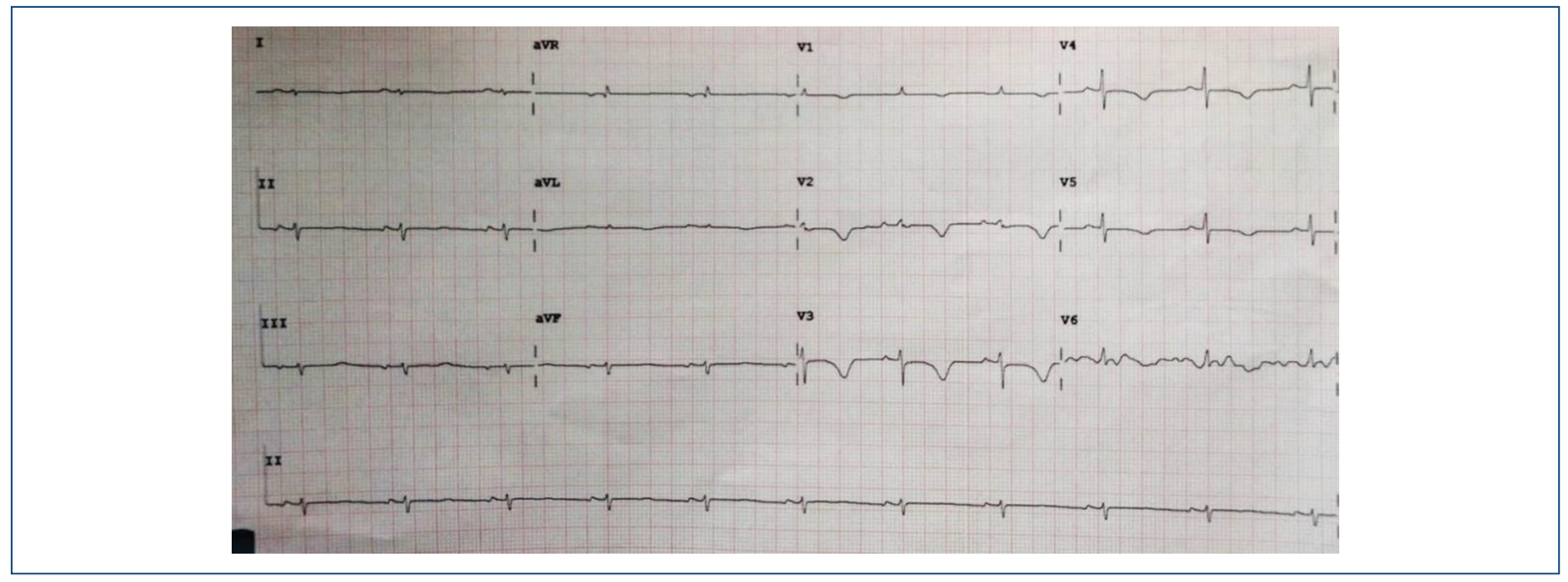

Figure 1. Patient electrocardiogram after the pericardial window with findings suggestive of Takotsubo cardiomyopathy.

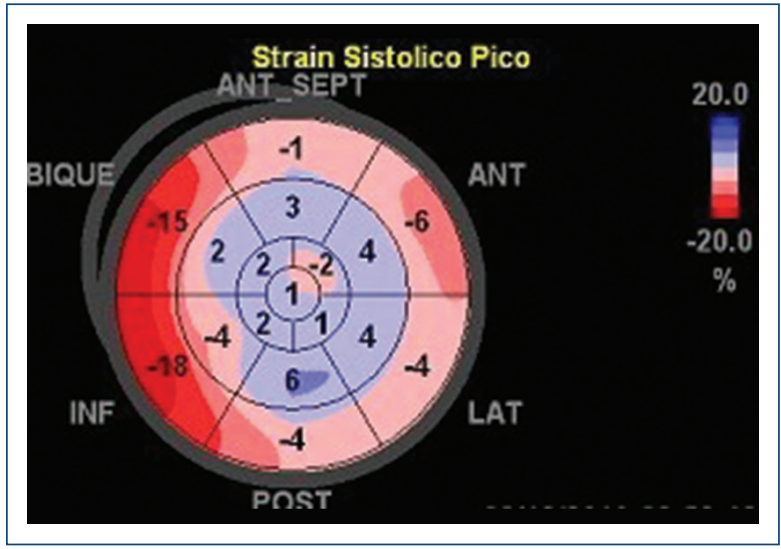

Figure 2. Left ventricular strain after the pericardial window with findings suggestive of Takotsubo cardiomyopathy.

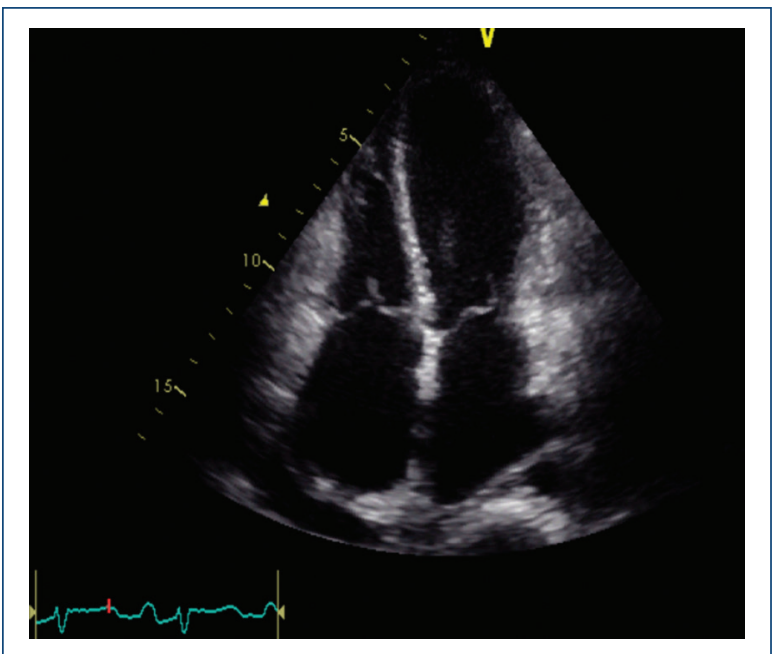

Figure 3. Four-chamber apical approach showing findings suggestive of biventricular Takotsubo cardiomyopathy.

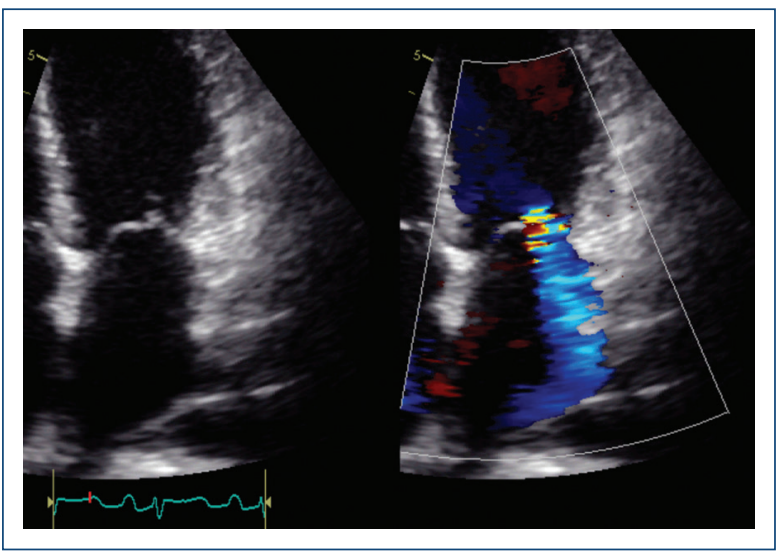

Figure 4. Four-chamber apical approach showing mitral valve regurgitation secondary to tethering.

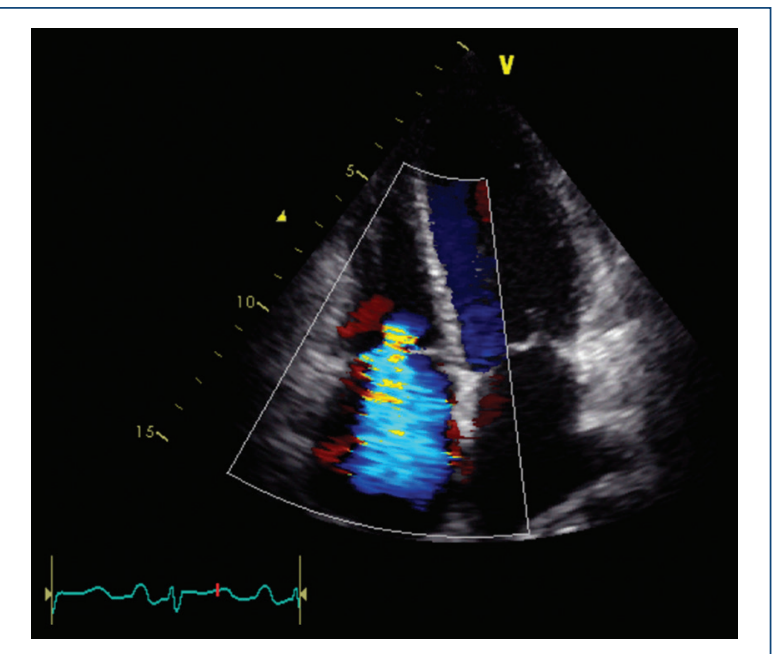

Figure 5. Four-chamber apical approach showing tricuspid valve regurgitation secondary to tethering. 
to several weeks after surgery. Clinically, this syndrome occurs up to $80 \%$ of the time with chest pain, in $50-60 \%$ with low-grade fever, and in $50-60 \%$ with dyspnea; there may be effusions in both the pericardium (> 80\%) and the pleura $(>60 \%)$ and pericardial friction rub in up to $30-60 \%$ of patients. Laboratory tests show elevated CRP (74\%) and leukocytosis ${ }^{1-3}$.

In our case, the patient attended the emergency department with tamponade and hemodynamic instability, which prompted the performance of emergency pericardial window. Takotsubo syndrome is well known to be secondary to elevated serum catecholamines, and physical or emotional stress can trigger the condition. In this case, both the tamponade and the surgical procedure itself could have acted as triggers for the development of stress cardiomyopathy.

Electrocardiogram and echocardiogram after the pericardial window showed findings that were previously well described in our patient, and that can be found in current literature on type I Takotsubo cardiomyopathy (InterTAK) ${ }^{4}$. Furthermore, left ventricular outflow tract obstruction has been documented in up to $20 \%$ of cases, which causes mitral regurgitation in acute phases. It is highly important to emphasize that in our patient there was mitral regurgitation that was not associated with left ventricular outflow tract obstruction (mean gradient of $5 \mathrm{mmHg}$ ), but rather with segmental mobility alterations that limit the closure of the posterior leaflet (leaflet tethering/Carpentier IIIB mitral regurgitation), associated with malposition of the mitral valve apparatus. Moreover, Takotsubo cardiomyopathy presentation with right ventricle involvement is not uncommon (an incidence of $34 \%$ is reported) $)^{5}$. Takotsubo's characteristic findings involving the right ventricle are related to dilation of the cavity and lateral wall alterations, which were present in this case with basal hyperkinesia and apical segment mobility alterations.

The non-invasive auxiliary method of choice for diagnosis is echocardiogram, since it allows to visualize systolic dysfunction distinctive pattern and to perform subsequent evaluations to demonstrate remission, as well as to identify cases with poorer prognosis (those with valve insufficiency due to anterior mitral valve anterior systolic movement or with left ventricular outflow tract obstruction due to basal hypercontractility, a condition that confers difficulty to the management of heart failure with inotropes, given that these can worsen the obstruction).

Treatment focuses on managing the heart failure. In case of hypotension and shock, the use of inotropes should be considered as a strategy to increase cardiac output. If these are not sufficient, the addition of vasopressors at low doses and for the shortest possible time should be considered as a bridge to improvement or a bridge to circulatory support with aortic counter-pulsation balloon or venoarterial ECMO ${ }^{6}$.

Up to $20 \%$ of patients with Takotsubo cardiomyopathy present with left ventricular outflow tract obstruction, which generates a greater decrease in cardiac output (already impaired by systolic dysfunction); therefore, understanding its pathophysiology is essential for its management. Any maneuver that favors ventricular contraction and collapse will favor an obstructive gradient; therefore, the use of inotropes should be avoided, while maneuvers that favor ventricular filling (such as increasing preload with solutions) are beneficial. The use of beta-blockers such as esmolol or metoprolol can also decrease the gradient by decreasing myocardial contraction. Finally, in cases that are refractory to these measures, the use of mechanical assistance devices should be considered, preferably assistance with $\mathrm{ECMO}^{7,8}$.

\section{Acknowledgments}

The authors would like to thank Instituto Nacional de Cardiología Ignacio Chávez of Mexico.

\section{Funding}

This research has not received specific aid from public or commercial sector agencies, or non-profit entities.

\section{Conflicts of interest}

The authors declare that they have no conflicts of interest.

\section{Ethical disclosures}

Protection of human and animal subjects. The authors declare that no experiments were performed on humans or animals for this research.

Confidentiality of data. The authors declare that no patient data appear in this article.

Right to privacy and informed consent. The authors declare that no patient data appear in this article.

\section{References}

1. Finkelstein Y, Shemesh J, Mahlab K, Abramov D, Bar-El Y, Sagie A, et al. Colchicine for the prevention of postpericardiotomy syndrome. Herz. 2002;27(8):791-4. 
Arch Cardiol Mex (Eng). 2021;91(1)

2. Imazio $M$, Trinchero $R$, Brucato $A$, Rovere ME, Gandino A, Cemin R, et al.; COPPS Investigators. COlchicine for the Prevention of the Post-pericardiotomy Syndrome (COPPS): a multicentre, randomized, double-blind, placebo-controlled trial. Eur Heart J. 2010;31(22) 2749-54.

3. Imazio M, Brucato A, Ferrazzi P, Pullara A, Adler Y, Barosi A, et al.; COPPS-2 Investigators. Colchicine for Prevention of postpericardiotomy syndrome and postoperative atrial fibrillation: the COPPS-2 randomized clinical trial. JAMA. 2014;312(10):1016-23.

4. Ghadri JR, Wittstein IS, Prasad A, Sharkey S, Dote K, Akashi YJ, et al International expert consensus document on Takotsubo syndrome (Part I): Clinical characteristics, diagnostic criteria, and pathophysiology. Eur Heart J. 2018;39(22):2032-46.
5. Eitel I, von Knobelsdorff F, Bernhardt P, Carbone I, Muellerleile K, Aldrovandi $A$, et al. Clinical characteristics and cardiovascular magnetic resonance findings in stress (Takotsubo) cardiomyopathy. JAMA. 2011;306:277-86.

6. Rashed A, Won S, Saad M, Schreiber T. Use of the Impella 2.5 left ventricular assist device in a patient with cardiogenic shock secondary to Takotsubo cardiomyopathy. BMJ Case Rep. 2015;2015:1-4.

7. Yoshioka T, Hashimoto A, Tsuchihashi K, Nagao K, Kyuma M, Ooiwa H, et al.Clinical implications of midventricular obstruction and intravenous propranolol use in transient left ventricular apical ballooning (Tako-tsubo cardiomyopathy). Am Heart J. 2008;155:1-7.

8. Bonacchi M, Maiani M, Harmelin G, Sani G. Intractable cardiogenic shock in stress cardiomyopathy with left ventricular outflow tract obstruction: is extra-corporeal life the best treatment? Eur J Heart Fail. 2009;11:721. 